\title{
The Impact of Using Non-Media Information Sources on the Future Use of Media Sources: The Mediating Role of Expectations Fulfillment
}

\begin{abstract}
An empirical study of 350 tourists reveals that using non-media information sources for planning tourist trip influences expectations fulfillment. The use of non-media information sources also has a direct impact on the future use of media information sources for future tourist trip planning, as well as an indirect impact through expectations fulfillment. More specifically, the main determinants of expectations fulfillment of local infrastructures are commercial brochures, travel agents and internet; expectations fulfillment of entertainment structures is affected by institutional brochures, travel agents and the internet; future use of media sources is influenced by expectations fulfillment of local infrastructures and entertainment structures; this factor is also influenced by past use of institutional brochures and the internet. Discussion centers on the implications of this model to theory and managerial development of tourism and services strategies. Directions for future research are also presented.
\end{abstract}

Subject areas: Services Marketing, Tourism, Information Sources, Media. 


\section{INTRODUCTION}

From a theoretical perspective, understanding consumer behavior is essential in decoding all the activities used to develop, communicate and sell services. Similarly, from a practioners' perspective it is required to understand the motives regarding why some services are preferred or rejected by consumers. With this understanding, it will be possible to influence consumers' decisions by developing appropriate strategies.

Consumer behavior study is much more complex for services than for goods, due to their intrinsic characteristics: intangibility, inseparability of production and consumption, heterogeneity, and perishability (Zeithaml, Parasuraman and Berry 1985). Tourist consumer behavior is particularly complex because the final decision of buying tourist services presents distinctive aspects. First, the acquisition process has a strong emotional component for consumers. Second, purchasing is often the culmination of a long process of planning, choice, evaluation and assessment of alternatives by a large number of people. Moreover, it is an investment with an intangible index of return. Tourists obtain only intangible satisfaction with the purchase (Moutinho 1987). More importantly, this intangibility of tourist services creates uncertainty and perceived risk in the consumer's mind (Hugstad, Taylor and Bruce 1987; Zeithaml 1981). So, before buying a tourist service, consumers acquire a large quantity of information and anticipate the consumption, creating images and expectations. 
Information search is a dynamic area of services research, with a relatively large conceptual and empirical basis. However, selection of information sources mostly explains "who, when, where, how and why" consumers search for information in the pre-purchase phase. Rare research (see Fodness and Murray 1999 as an exception) indicates that the use of information sources influences future search behaviors.

To our knowledge, no research exists regarding the impact of information search patterns on future information search behaviors. Moreover, although a wide range of empirical studies have been developed concerning the impact of information sources on expectations, no empirical study has analyzed the impact of expectations fulfillment on the future use of information sources. Previous research indicates that expectations fulfillment is shaped through information sources that consumers obtain in the pre-purchase stage (Webster 1991, Spreng and Page 2001). Since future consumer choices are based on expectations, a better understanding of this relationship is vital to marketing managers (Anderson and Salisbury 2003). By understanding how consumers will search for information, we have a basis to influence consumers' expectations (McColl-Kennedy and Fetter Jr. 1999). Information search in the pre-purchase stage strongly influences overall consumer decision, mainly because it influences consumers' images and expectations (Murray 1991). Similarly, the process of expectations formation in the tourism industry is particularly relevant given that tourists make their purchase decisions while building on expectations (Gartner 1989). Tourists typically travel to a place different from their residence and in several cases to a place where they had 
never been before. To explore or reduce the risk of unfamiliar product experimentation, tourists seek information (Dodd, Pinkleton and Gustafson 1996) and create destination expectations (Baloglu and Brinberg 1997). Hence, since tourism products are perceived by consumers while taking into consideration their service expectations (Parasuraman, Zeithaml and Berry 1988), these expectations become a major influence on consumer choices (Neelamegham and Jain 1999).

Common sources that provide customized information are travel agents, institutional and commercial brochures, and the internet. Marketers use these sources to build tourists' specific expectations with the goal of influencing future purchase decisions (Murray 1991). Tourists' product image might also be affected by non-customized information. This information is typically not requested by consumers and is normally provided in the form of media reports and media advertising. It is our aim to develop a model that assesses the importance of non-media information sources, and their impact on expectations fulfillment and on future use of media sources. In addition to media sources, we include four non-media sources: travel agents, institutional brochures, commercial brochures and the internet. These non-media sources are used by tourists in information search to select the route to the destination, selection of accommodation, and selection of activities in the chosen destination.

This article is organized into the following sections. An overview of the current literature is offered. The different sources are introduced and the conceptual framework is tested via a survey of 350 tourists. Empirical results 
are presented. Implications for theory and managerial practice, limitations of the research and future directions are also considered.

\section{CONCEPTUAL FRAMEWORK AND HYPOTHESES}

Service consumers tend to evaluate information in a more complex and distinctive way than consumers of goods because they are in a context of perceived risk and, hence, need much more information than when evaluating a good (Murray 1991). More specifically, tourist activities involve a high perceived risk. This occurs because tourists typically travel to a place other than their residence, and in several cases to a place where they have never been before (Murray 1991). Tourists seek information to explore or reduce the risk of unfamiliar product experimentation (Dodd, Pinkleton and Gustafson 1996). They create expectations by creating a destination image through many sources, such as non-media tourism marketing sources and media sources (Stabler 1988). Tourist-induced images are created through the received information from external sources (Gartner 1989).

In this study we develop a conceptual model (see Figure 1) in a tourism context, where we analyze how the use of non-media information sources directly and indirectly influences future use of media sources through consumer expectations.

Insert Figure 1 about here 


\subsection{TOURISM INFORMATION SOURCES}

Information search exists at the internal and external level (cf. Bettman and Park 1980). In this study we focus at the external level, namely on information sources that can be controlled by tourism institutions. While internal information search consists of information acquisition in the individual's memory, formed by consumer experiences, external information is acquired in the environmental context. External search is a conscious and motivated decision to acquire information from the consumer's environment (Murray 1991). It is associated with the "degree of attention, perception, and effort directed toward obtained environmental data or information related to the specific purchase under consideration" (Beatty and Smith 1987: 85). Consumers choose information sources in a limited number that will help them to plan their consumption process better, in a way to reduce the level of perceived risk (Murray 1991).

Tourism search typically uses a variety of external information sources (Moutinho 2000). These information sources form the basis for trip planning (Snepenger et al. 1990). When searching for tourist information one must consider the variety of sources used (Beatty and Smith 1987; Srinivasan and Ratchford 1991). From both theoretical and practitioner perspectives, it is particularly useful to study the importance of specific information sources used by tourists for services selection (see: Brucks 1985; Murray 1991; Fodness and Murray 1999). 
Literature on services, namely in the tourism field, suggests that information search involves more information sources than other products. Information acquisition is necessary for purchase decisions after the destination selection, such as choosing accommodation, transportation and activities (Filiatrault and Ritchie 1980; Jenkins 1978; Perdue 1985). Specific combinations of tourist information sources acquired and used in the planning process represent the information search strategies (Fodness and Murray 1999).

In this study we considered two types of information sources: non-media (institutional and commercial brochures, travel agents and internet) and media information sources (advertising and reports in media channels). This dichotomy is based on the assumption that tourists can reach information in two ways: actively and non-actively. In the first case, tourists are motivated and search for information with a purpose: to reduce the uncertainty of new product experimentation. They search for brochures, go to travel agencies or look for information on the Internet to build their own information about destinations. In the case of media sources, the information is not requested. Tourists are confronted with mass-targetted messages (e.g. advertising or media reports) while they read the newspaper, watch TV or listen to the radio. In conclusion, the dichotomy of non-media and media information sources is based on customized and non-customized information provided to the masses.

We will now discuss the different types of information sources included in our model. 


\subsubsection{NON-MEDIA INFORMATION SOURCES}

\subsubsection{Information from brochures}

In line with previous studies (Fodness and Murray 1999; Raitz and Dakhil 1989), we make the distinction between institutional and commercial brochures. Although researchers often analyze information provided in brochures from a broad perspective, this distinction is essential, because while commercial brochures are controllable by tourism service enterprises (e.g. hotels, restaurants), the same does not apply to institutional brochures that are produced by tourist or local organizations (tourism offices and local government organizations) $)^{1}$

\section{Information from institutional brochures}

When planning their trips, tourists tend to use informative travel brochures as a key source of information. These sources are very informative and reliable due to their institutional nature, namely due to the fact of being provided by the tourism destinations and associated institutions (Nolan 1976). Many authors have included these sources in their studies. For example, Snepenger and colleagues (Snepenger 1987; Snepenger et. al. 1990) reported that group tourism travelers use institutional brochures during their information search. This is also confirmed by other studies, which reveal that institutional brochures are considered to be a major source of trip-planning information

\footnotetext{
1 In order to differentiate institutional from commercial brochures to respondents these two information sources were presented in the following way: commercial brochures as brochures of travel agents, guidebooks, brochures of hotels; and institutional brochures as Municipal, local, national or institutional informative brochures.
} 
(Raitz and Dakhil 1989), and tend to be used by travelers with high income (Fodness and Murray 1999).

\section{Information from commercial brochures}

Much of the travel and tourism industry relies on commercial brochures. Tourism services use brochures as a privileged advertising channel. For example, travel agencies and operators typically use these sources to provide their clients with concrete information about different themes (e.g. hotels, destinations, recreation parks). Commercial brochures tend to be very effective because the consumer pays nothing for these expensive publications, and they help consumers to avoid risk perception. Very recently, Bieger, Laesser and Gallen (2000) demonstrated that commercial brochures from hotels and tourist operators are regularly used as key information sources to select a tourism destination.

\subsubsection{Travel agents}

Service consumers tend to have a great preference for personal sources of information, especially when acquiring a complex service, such as a touring excursion (Murray 1991). Through their sales force, travel agencies can constitute one of those personal sources. Like other service providers, tourism agencies might use their sales force (i.e. the travel agents) to create a favorable image (see: Zeithaml, Parasuraman and Berry 1985). Travel agents add value to the tourism industry in several ways. They are geographically close to the tourist and assist the customer by doing much of the searching on their behalf. They are also able to cater to the individual requirements of each tourist and can customize a holiday to suit each client. As the closest intermediary to the 
customer, they are in the best position to build relationships with customers (Wynne et al. 2001).

Earlier research suggests that personal sources are preferred because they are more reliable than non-personal information sources (Murray 1991). The tourism activity is a high-risk situation with a strong social component. Within this context, personal information sources might play a major role in clarifying problematic issues, while providing feedback to service customers.

Travel agents have played and will continue to play an important role as information sources (Connolly and Olsen 2001). Indeed, since the early work of Nolan (1976), travel agents have been considered as a source of information examined in several tourism studies. For example, Shoemaker (1984) observed that travel agents were consulted about routes, accommodation and activities at the destination. Travel agents were also proved to be a useful source of information for older travelers (Gitelson and Crompton 1983; Shoemaker 1984) and the most-used source for tourism at both the individual and group levels (Snepenger 1987). Although there are many tourists who do their own search, they tend to habitually use travel agents to make their bookings. Tourists still exhibit a preference for booking through travel agents and appreciate human interaction and personal advice (Ader, LaFleur and Falcone 2000; Morrison and King 2002).

\subsubsection{Internet}

Nowadays, the internet is assumed to be an important channel for services marketing. The internet is leading to profound changes in the way firms interact with consumers. Consumers now have increased access to informational 
electronic marketplaces and use this information in a sophisticated way to select their services (Parasuraman and Zinkhan 2002). It provides accurate and specific information that can reach the target audience with the accuracy of more personalized information sources (Leong, Huang and Stanners 1998). This new interactive medium can be considered a rational medium (Leong, Huang and Stanners 1998) of difficult classification. The internet is not easily classified as either impersonal or a media channel (Reardon and Rogers 1988).

Indeed, the internet was pointed out as being responsible for a revolution in the services sector. Its potential allows service firms to enlarge their market worldwide (Lovelock et al. 1999), providing firms with an unprecedented ability to communicate directly and effectively with potential customers. This is due, among other things, to the cost-effectiveness of the Internet and the convenience for customers. Increasing digitalization will make it progressively easier to alter particular aspects of a service and quickly observe how customers respond (Wyner 2000).

In the tourism sector, the internet has become an important source of information to consumers who are more and more demanding, and who become each day more familiarized with this emerging world of information. Tourism has historically been an early adopter of new technology (Bloch 1996; Wynne et al. 2001). As in other service sectors, technological developments are altering the nature of the processes in the tourism sector (see: Connel and Reynolds 1999).

With the relatively widespread adoption of the Internet, tourism businesses of all sizes might expand and acquire new customers and create more 
sophisticated products to reach new customer segments. In recent years, firms have started to customize their products and campaign contents to specific market segments (Beldona 2005). Increasingly more demanding and sophisticated travelers seek information about more exotic destinations and different experiences. Tourists have become more independent and sophisticated in using a range of tools to arrange their travel (Buhalis 1998). The key to the tourist's decision is the existence of relevant information. With the internet such information might be available and more accessible (Connel and Reynolds 1999). Customer satisfaction depends on the accuracy of specific information on destinations' accessibility, accommodations, facilities, attractions and activities. The internet satisfies the needs of consumers for convenient access to transparent information. It allows them to compare information. They are able to cover the entire variety of choices of travel, accommodation, transportation and leisure services, holiday packages, prices and availability (Buhalis 1998). This type of information will naturally help tourists to plan complex tourist activities, such as the planning of long trips (Bieger, Laesser and Gallen 2000). The interactive nature of the World Wide Web affords tourist services users with a simpler and more advantageous buying process. Consumers have more and varied information; there is less bureaucracy and paperwork; clients have a more personalized and customized relationship with the suppliers (Buhalis 1998).

\subsection{FULFILLMENT OF EXPECTATIONS}

Destination images are formed based on the information acquired from different sources (Gartner 1989). Resulting images influence perceived expectations. Expectations are associated with what consumers feel or desire 
from a service (Parasuraman, Zeithaml and Berry 1988). Customer intentions to use or reject a service will naturally be influenced by these expectations (Dorsch, Grove and Darde 2000; Webster 1991).

Expectations are associated with consumer predictions about a service performance. They are beliefs about something that will happen in the future, so they present a certain degree of uncertainty (Spreng and Page 2001). To reduce that perceived uncertainty associated with services, consumers search for information (Zeithaml 1981). Due to high human and financial costs, the decision to make a vacation trip to a destination will normally be taken after extensive information search. Prior to buying a tourist excursion, marketing begins with the identification of a specific need. This need leads to an anticipation process of the final product consumption that may satisfy it (Engel et. al 1993). Consumption expectations will help consumers to anticipate and to make plans creating and anticipating images of a specific product, its uses and consequences. By forming different visions, consumers may mentally experiment with alternatives and choose the one that will give them more pleasure during the consumption (Bieger, et al. 2000).

Expectations of tourist destinations are a particularly rich area of tourism research (Echtner and Ritchie 1991, 1993; Ahmed 1996). For example, an attribute list to measure the destination characteristics was proposed by Echtner and Ritchie (1991). This list includes attributes such as the amicability of the destinations inhabitants, city and regional beauty (e.g. landscape/natural beauty), dining services; and attributes concerning infrastructures and entertainment, such as monuments, local attractions, and tourist events. This study has a 
number of variables related to the destination attributes associated with a region. The attributes were divided into two different constructs: those related to the region-specific characteristics (inhabitants' friendliness, beauty of city and region, quality of dinning services), and those related to local infrastructures and entertainment.

Tourists try to fulfill their expectations visiting the destination. Once there, they compare the information gathered in the planning phase with reality. Tourists gathering complete and varied information will be well informed about the specific destination that they visit. Hence, we can assume that there will be few or no surprises for them. We can therefore expect that these tourists will fulfill their expectations easily.

In line with previous discussion, it is suggested that expectations fulfillment is positively affected by information acquired from various nonmedia sources (Webster 1991; Spreng and Page 2001). Therefore, it is expected that the fulfillment of tourist destination expectations regarding the characteristics of the region as well as local infrastructures and entertainment structures are positively affected by information acquired from different sources. More specifically:

H1. The expectations regarding the characteristics of the region are affected by:

H1a. Institutional brochures.

H1b. Commercial brochures.

H1c. Travel agents.

H1d. Internet. 
H2. The expectations fulfillment regarding local infrastructures and entertainment structures is affected by:

H2a. Institutional brochures.

H2b. Commercial brochures.

H2c. Travel agents.

H2d. Internet.

\subsection{THE RELATIONSHIPS BETWEEN FULFILLMENT OF EXPECTATIONS AND FUTURE USE OF MEDIA SOURCES}

During the last decades, quite a number of empirical studies concerning the impact of information sources have been developed. These studies conclude that information gathered in media channels have a strong impact on expectations fulfillment (Dorsch, Grove and Darde 2000, Neelamegham and Jain 1999, Smith 1993). In this study we suggest that future use of media information is affected by expectations fulfillment.

Media are a key communication channel for service firms because they present immediate benefits to consumers (Zeithaml, Parasuraman and Berry 1985). Although this search provides a greater variety of information to solve a specific information problem (Dodd, Pinkleton and Gustafson 1996), it does not provide customized information. Consumers spend more time and effort than when collecting information from customized sources, as media act independently of the consumers' active process of information search (Gartner 
1989). It is considered as a formal (Raitz and Dakhil 1989) and impersonal information source (Hugstad, 1987). Media have a volunteer character and include media reports and media advertising (Raitz and Dakhil 1989). Media reports have been pointed out by many investigators as an important information source, mainly because they are considered by consumers as a neutral and independent source (Mitra, Reiss and Capella 1999; Beatty and Smith 1987).

Marketers can also influence consumers' perceptions about a specific tourist product by controlling the content and frequency of media advertising (Dorsch, Grove and Darde 2000). Advertisers present their brands and products in the most favorable way (Moore and Lutz 2000). They construct their advertising messages emphasizing the benefits that consumers may realize buying their service products (Zeithaml, Parasuraman and Berry 1985; Moutinho and Goode 1995).

Advertising also has an important role in the tourist destinations marketing strategies (Siegel and Ziff-Levine 1990), due to the complexity of that type of product (Manfredo 1989). Advertising gives tourists unique experience before they buy the product. Ads give a direct sensory contact with the product (Kempf and Smith 1998) while making a strong impact on consumer minds (Moore and Lutz 2000). More specifically, advertising and media information are co-related with expectancy formation of brand attitudes before trial (Smith 1993).

Some satisfaction models show that fulfillment of tourists' expectations is usually co-related with media information (Neelamegham and Jain 1999). Research indicates that fulfillment of tourists' expectations is influenced by 
media information. The most relevant information inputs include television advertising and critic reviews (Neelamegham and Jain 1999). However, in this research we are particularly interested in better understanding the opposite relationship, i.e. how fulfillment of expectations will influence the future of media sources, because it is believed that consumers are reactive to previous experiences. Hence,

H.3. Future use of media information is influenced by fulfillment of destination expectations associated with:

\section{H3a) Regional Characteristics}

H3b) Local infrastructures and entertainment.

\subsection{THE RELATIONSHIP BETWEEN USE OF NON-MEDIA INFORMATION SOURCES AND FUTURE USE OF MEDIA SOURCES}

As previously discussed, tourists gather information from a variety of non-media information sources to support tourism decisions. That information is acquired mainly from formal sources, i.e. created by marketers with the specific purpose of promoting tourism planning activities. Those sources include institutional and commercial brochures, salespeople and electronic media (Raitz and Dakhil 1989).

Media information is usually not requested, it is offered to consumers while planning tourism trips (Gartner 1989). On the other hand, information gathered in media sources is generally more appealing and varied than the information gathered in non-media sources (Dodd, Pinkleton and Gustafson 1996). Hence, the preceding use of non-media information sources in trip planning is likely to be related to future use of media information sources in 
future trip planning. Not all non-media information sources have the same relationship with future usage of media information. Commercial and institutional brochures have a positive relationship, but travel agents and the internet have a negative relationship.

The importance of brochures information in tourist products has been defended by a large number of authors. Many studies have concluded that institutional brochures (Fodness and Murray 1999; Nolan 1976; Raitz and Dakhil 1989; Snepenger 1987; Snepenger et. al. 1990) and commercial brochures (Bieger, Laesser and Gallen 2000; Snepenger et al. 1990) are important information sources for tourists as they plan their trips. When they visit the tourist destinations they consolidate the information acquired previously in those brochures. However, in the future, tourists will use different sources, such as media information to plan their trips. Destination image is formed with sources such as advertising and travel brochures (Gunn 1972), particularly, when planning trips with high risk perception (Fodness and Murray 1999). In sum, it is expected that:

H.4. The use of institutional brochures in trip planning will lead to the utilization of media information sources in the future.

\section{H.5. The use of commercial brochures in trip planning will lead} to the utilization of media information sources in the future.

\subsubsection{MEDIA AND TRAVEL AGENTS}

Tourism activity is considered as a high-risk purchase situation with a strong social component. Generally, in purchase decisions with a high perceived risk, consumers tend to rely on personal sources (Mitra, Reiss and Capella 
1999). Consumers use information from personal channels in situations in which perceived risk and uncertainty have not been reduced sufficiently by formal information sources.

Service consumers and especially tourists have greater confidence in personal sources (Murray 1991; Mitra, Reiss and Capella 1999). Salespeople are particularly important in this kind of purchase (Hugstad, Taylor and Bruce 1987). Personal sources are preferred because they are more reliable than nonpersonal information sources. Consumers' preference for personal sources is due to two factors: flexibility and credibility (Mitra, Reiss and Capella 1999). However, this fact of reliance on personal sources does not reduce the need for effective advertising and public relations. Consumers utilize greater personal information search, but they also use a greater level of non-personal information (Mitra, Reiss and Capella 1999). This leads us to the following hypothesis:

\section{H.6. The use of travel agent information in trip planning will lead to less utilization of media information sources in the future.}

\subsubsection{MEDIA INFORMATION AND INTERNET}

The internet represents an efficient medium for accessing, organizing and communicating tourist information (Peterson, Balasubramanian and Bronnenberg 1997). It has a clear advantage over traditional media (Kaid 2002), giving unique benefits which are unavailable in traditional media environments (Ghose and Dou 1998).

The internet as a communication medium is unique to tourists in several dimensions, such as interactivity, control, dynamics and content (Hoffman and 
Novak 1996, Menon and Soman 2002). It is a better communication channel because traditional media channels limit audience behavior options and information usage (Kaid 2002). First, the internet provides more and varied information. Second, it offers more possibilities for seeking tourist information. Third, tourist net users have the ability to control their information usage.

Finally, information obtained on the internet is more interactive (Kaid 2002) and provides perceptual experiences to tourists that are far superior to other media (Rust and Varki 1996).

To sellers, the internet is more flexible than existing media channels. It is potentially superior in targeting individual and perspective buyers and gives the possibility of direct interaction with tourists. It has the ability to inexpensively store vast amounts of information at different virtual locations. It can serve as a transaction medium and has low costs for sellers (Rust and Varki 1996). Some authors argue that soon internet use will functionally replace traditional media (Rust and Varki 1996).

\section{H.7. The use of internet information in trip planning will lead to a decrease in the utilization of media information sources in the future.}

\section{METHODOLOGY}

\subsection{THE RESEARCH SETTING}

The research setting was a European country (Portugal) in the tourism service more specifically, in the hotel services sector. As one of the most important areas of tourist activity, the hotel sector becomes important to the 
definition of tourism, since the UNO (United Nations Organization) defines tourists as temporary visitors who stay at least 24 hours in a tourist site which is visited for pleasure activities. This definition implies the use of lodging structures. The most recent data show that this country has increased its tourism market exponentially. There are high expectations for the future, given that Portugal is now one of the leading countries in terms of conditions and potentialities in the tourism services market, especially as far as European tourists are concerned (Miles 1995; Murphy and Murphy 2002, Wise 2005).

\subsection{DEVELOPMENT OF SURVEY INSTRUMENT}

We developed a measurement scale to capture the importance that tourists give to the information sources in their trip planning. In an early stage, we used previously-established scales (Furse, Punj and Stewart, 1984; Raitz and Dakhil 1989) to develop our survey instrument. The initial scales were then translated into Portuguese and adjusted to tourism services user reality. These scales were then discussed with people capable of understanding the nature of the concept being measured. All the items were assessed through a seven-point Likert scale (ranging from "1- not important at all" to "7- extremely important"). The questionnaire was initially developed in Portuguese and then translated into English, French, Spanish and German. After revisions, we used a pre-test sample of 30 tourism students in order to test the reliability of the scales (through Cronbach alpha). The pre-test results were used to refine the questionnaire further. In order to avoid translation errors, the questionnaires were back- translated into Portuguese. 


\subsection{DATA COLLECTION}

The final data collection was conducted from December of 2002 to September of 2003. During this time there were some events that attracted many tourists to Portugal, such as the World Handball Championship and the European Football Championship. Tourists were randomly selected in loco across 19 hotels that agreed to participate in the study. The questionnaires (together with a presentation letter explaining the objective of this study) were delivered by the hotel receptionists to the tourists at the moment they were leaving the hotel. This allowed us to ensure that the data were not biased and that tourists had significant knowledge about the topic. A final sample of 350 questionnaires was obtained. Tourist from many countries participated in the survey.

\subsection{PROFILE OF RESPONDENTS}

The Portuguese tourist market consists primarily of European consumers. Tourists from many countries participated in the survey. Over $60 \%$ of the respondents were Portuguese tourists. The rest of the sample was composed mostly of European tourists from Spain (11\%), Germany (10\%), France (5\%) and the United Kingdom (5\%). Other less represented countries in the sample include Italy (2\%), Belgium (1\%), USA (1\%), Greenland (1\%), Austria and Sweden (1\%), as well as countries with a single tourist (Australia, Brazil, Bulgaria, Denmark, the Netherlands, Iceland, Ireland, Israel, and Qatar). Most of the tourists were single $(19 \%)$ or married with children $(60 \%)$. More than $40 \%$ of the respondents had university education and almost $40 \%$ had completed high school. Also, the respondents indicated how often they were on 
holidays per year. $45 \%$ responded once, $37 \%$ twice, and $14 \%$ three times.

Tourists in the sample usually spent two to five nights away on these trips (two nights $-11 \%$, three nights $-28 \%$, four nights $-10 \%$, five nights $-20 \%$ ). They were also asked how many business trips they made in the year on average and how long those trips were. The answers ranged between $0(31.1 \%), 1-5$ times (33.9\%), 6-10 (6\%), 11-15 (10.6\%), and more than 16 times (18.4\%); and regarding the number of nights, the respondents indicated that they usually spent zero nights (30.6\%), 11.4\% spent one night, $31.4 \%$ two, $13.1 \%$ three, $7.1 \%$ four and $6.3 \%$ more than five nights. They were asked to answer the same questions with regard to leisure trips. A large part of the sample responded that on average they have two leisure trips (34.9\%), 19.1\% have one, $18.6 \%$ more than four, $17.7 \%$ three and only $9.7 \%$ of the subjects had no such trips. The respondents usually spend two to five nights away on these trips (three $-28 \%$, five $-19.7 \%$, two $-10.9 \%$ and four $-10.3 \%)$. A large percentage of the tourists had visited this destination more than 10 times in the previous three years $(45.9 \%), 33 \%$ had visited fewer than 10 times, and $21.1 \%$ were visiting Portugal for the first time. Concluding, one might say that these tourists vacationed at least once a year, many with one to four night business trips, one to five times, and mostly two short leisure trips on average per year.

The respondents were also asked to indicate the mode of transportation (over $50 \%$ of the sample traveled by car and many came by plane), and the purpose of this trip (30\% were on business, and about $50 \%$ were on leisure, came to visit specific tourist attractions, monuments or to attend a special event or to know this destination $-23 \%, 17 \%$ and $11 \%$ respectively). 
To almost $50 \%$ of the tourists this was a long trip (43.6\% of the respondents stayed more than 6 nights. When we asked how long they spent planning this trip almost $60 \%$ responded that they needed one to ten days, only $12.6 \%$ did not need to plan this trip. The sample was made up mostly of leisure tourists who came in their own car or by plane to visit this destination especially or to participate in a specific event ${ }^{2}$. These tourists did not need much time to plan this trip.

\section{RESULTS}

\subsection{CONFIRMATORY FACTOR ANALYSIS}

In order to assess the validity of the measures, the items were subjected to a confirmatory factor analysis, using full-information maximum likelihood (FIML) estimation procedures in LISREL 8.3 (Joreskog and Sorbom 1993). In this model, each item is restricted to load on its pre-specified factor, with the seven factors allowed to correlate freely. The chi-square for this model is significant $\left(\mathrm{X}^{2}=708.38,168 \mathrm{df}, \mathrm{p}<.00\right)$. Since the chi-square statistic is sensitive to sample size, we also assessed additional fit indices: the Comparative Fit Index (CFI), the Incremental Fit Index (IFI), and the Tucker-Lewis Fit Index (TLI). The CFI, IFI, and TLI of this model are $.91, .91$, and .88 , respectively. Since fit indices can be improved by allowing more terms to be freely estimated, we also assessed the Root Mean Square Error of Approximation (RMSEA), which assesses fit and incorporates a penalty for lack of parsimony. An RMSEA

\footnotetext{
${ }^{2}$ The Championship of Handball and Football contributed heavily to these responses.
} 
of .05 or less indicates a close fit to the population, while .08 to .10 indicates a satisfactory fit, with any score over .10 indicating an unacceptable fit. The RMSEA of this measurement model is .096. Convergent validity is evidenced by the large and significant standardized loadings of each item on its intended construct (average loading size was 0.84 ). Discriminant validity among the constructs is stringently assessed using the Fornell and Larcker (1981) test; all possible pairs of constructs passed this test. Appendix A presents all the constructs, scale items and reliabilities.

\subsection{STRUCTURAL MODEL ESTIMATION}

The conceptual framework of Figure 1 is simultaneously estimated in a structural equation model using FIML estimation procedures in LISREL 8.3. Specifically, this model contains seven constructs, 21 observable indicators, measurement and latent variable errors, and inter-correlations between the latent constructs. Specifically, the correlations between similar constructs (e.g., commercial brochures, institutional brochures, travel agents and internet) were freely estimated. The estimation results for the significant structural paths are shown in Figure 2. This model has a chi-square of 708.38 (168 df, $\mathrm{p}<.00)$; the fit indices suggest a good fit of the model to the data $(\mathrm{CFI}=0.91$, IFI= 0.91 , TLI=.88, RMSEA=0.096).

Insert Figure 2 about here 


\subsubsection{TEST OF HYPOTHESES}

An examination of the individual paths in Table 1 indicates that institutional brochures exert no significant effect on expectations fulfillment regarding region characteristics (H1a is not supported). However, institutional brochures have a significant positive direct impact on expectations fulfillment of local infrastructures and entertainment structures $\left(\gamma^{21}=.21, \mathrm{t}=2.61\right)$. Hence, $\mathrm{H} 2 \mathrm{a}$ is supported. Contradicting $\mathrm{H} 1 \mathrm{~b}$ and $\mathrm{H} 2 \mathrm{~b}$, commercial brochures have a negative and highly significant effect on expectations fulfillment of regional characteristics $\left(\gamma^{12}=-.55, \mathrm{t}=-3.13\right)$ and no significant impact on local infrastructures and entertainment structures. Travel agents have a significant and positive impact on expectations fulfillment concerning the characteristics of the region $\left(\gamma^{13}=.70, \mathrm{t}=4.20\right)$ and local infrastructures $\left(\gamma^{23}=.37, \mathrm{t}=2.36\right)$. Thus, there is support for $\mathrm{H} 1 \mathrm{c}$ and $\mathrm{H} 2 \mathrm{c}$. As predicted by $\mathrm{H} 1 \mathrm{~d}$ and $\mathrm{H} 2 \mathrm{~d}$, the internet has a significant and positive impact on expectations fulfillment of the characteristics of the region $\left(\gamma^{14}=.18, \mathrm{t}=2.62\right)$ and local infrastructures and entertainment structures $\left(\gamma^{24}=.20, \mathrm{t}=3.04\right)$.

Insert Table 1 about here

When testing $\mathrm{H} 3 \mathrm{a}$, we found no significant relationship between expectations fulfillment regarding regional characteristics and the future use of media information sources. However, consistent with $\mathrm{H} 3 \mathrm{~b}$, we conclude that 
there is a significant impact of expectations fulfillment of local infrastructures on the future use of media sources $\left(\beta^{32}=.43, \mathrm{t}=6.55\right)$.

Consistent with $\mathrm{H} 4$, the results support that the use of institutional brochures in the past positively affects future use of media information sources $\left(\gamma^{31}=.42, \mathrm{t}=5.82\right)$. When testing H5 and H6, we found no significant effect of commercial brochures' and travel agents' usage on the use of media information sources for future trip planning. Surprisingly, when testing H7 we found that past internet usage positively affects future use of media information sources in future trip planning $\left(\gamma^{34}=.15, \mathrm{t}=2.69\right)$.

\subsubsection{RELATIVE IMPORTANCE OF EACH VARIABLE AND}

\section{INDIRECT EFFECTS}

One of the key advantages of using a path model is the possibility of estimating not only the direct effects, but also the indirect and total effects among latent variables (Lages and Lages 2004; Lages and Montgomery 2004; 2005). Table 1 shows that two out of the four possible indirect effects are statistically significant. Both the direct $\left(\gamma^{31}=0.42, \mathrm{t}=5.82\right)$ and indirect $(0.09$, $\mathrm{t}=2.55$ ) impact of institutional brochures on the future use of media sources are found to be positively statistically significant. Consequently, the indirect relationship strengthens the total effect $(0.51, \mathrm{t}=6.42)$. Similarly, both the direct $\left(\gamma_{34}=0.15, \mathrm{t}=2.69\right)$ and indirect $(0.08, \mathrm{t}=2.77)$ impact of internet usage on the future use of media sources are found to be positively statistically significant, strengthening the total effect $(0.24, \mathrm{t}=3.83)$.

When comparing the standardized coefficients effects among variables (see Table 1), we found that the main determinant of expectations fulfillment of 
regional characteristics is the use of travel agents $\left(\gamma^{13}=0.70, t=4.20\right)$, followed in relative importance by a negative impact of commercial brochures $\left(\gamma^{12}=-0.55, \mathrm{t}=\right.$ $-3.13)$ and positively by internet $\left(\gamma^{14}=0.18, \mathrm{t}=2.62\right)$.

Regarding the main determinants of expectations fulfillment of local infrastructures and entertainment structures, we found that the most important determinant is travel agents' use $\left(\gamma^{23}=0.37, \mathrm{t}=2.36\right)$, followed in relative importance by a negative impact of commercial brochures $\left(\gamma^{22}=-0.28, \mathrm{t}=-\right.$ 1.66) and the internet $\left(\gamma^{24}=0.20, \mathrm{t}=3.04\right)$, which have a similar impact on expectations fulfillment of local infrastructures and entertainment structures.

Regarding the main determinants of future use of media sources, we found that the two most important determinants are expectations fulfillment of local infrastructures and entertainment structures $\left(\beta^{32}=0.43, \mathrm{t}=6.55\right)$ and institutional brochures usage $\left(\gamma^{31}=0.42, \mathrm{t}=5.82\right)$, which are approximately three times more important than internet $\left(\gamma^{34}=0.15, \mathrm{t}=2.69\right)$.

\section{MANAGERIAL IMPLICATIONS}

Existing models of tourist information search offer a restrictive vision of information search. These models consider information search only as a prepurchase phase, namely in destination choice and trip planning. Our model gives a more extended and integrated vision of tourist information search in all phases of tourist decision making. Information sources are an important channel for reducing the uncertainty about tourists' destinations and creating and fulfilling tourists' expectations. When marketers understand how consumers search for 
information, they can create more effective campaigns to influence consumers' expectations (McColl-Kennedy and Fetter Jr. 1999).

Along these lines we can state that non-media information sources should be used by tourist organizations marketers, namely institutional brochures, travel agents and internet, because they contribute positively to tourist destination expectations fulfillment. Also, commercial brochures are an information source to avoid. They have a negative impact on expectations fulfillment. Marketers should use media information sources. Tourists in our sample showed that they will use them in future trip planning. Communication campaigns should not be restricted to information about local infrastructures, but should also include information related to more general characteristics about regions. Finally, internet and institutional brochures should be used by tourist organizations, taking into account that these information sources have a positive influence on future use of media.

\section{LIMITATIONS AND DIRECTIONS FOR FUTURE}

\section{RESEARCH}

There are some limitations of the research to be considered. The first limitation is that the final instrument (i.e. the questionnaire) may have created common method variance that could have inflated construct relationships. This could be particularly threatening if the respondents were aware of the conceptual framework of interest. However, they were not told the specific purpose of the study, and all of the construct items were separated and mixed so 
that respondents would not be able to detect which items were affecting which factors.

Second, this model should be more developed with regard to expectations fulfillment and future search behaviors. Namely, another construct should be introduced and tested that might have a strong impact on information search behaviors - information search credibility.

A third limitation is related to sample characteristics which may limit the generalization of the results to some degree. The research context includes domestic tourists in Portugal, some of them with experience in the tourist destination. Future studies with larger samples could allow for a comparison between national and foreign tourist behavior as well as between experienced and non-experienced tourists.

Further research is also required to better understand tourists' decisions. Decisions may also be influenced by unconscious factors and by information sources that are not strictly tourism-related (e.g. arts, novels, movies). Since consumers make decisions based on factors that they are not even consciously aware of, future research is strongly encouraged to use qualitative methodologies to better understand this phenomenon. ${ }^{3}$ Moreover, further research is required when analyzing the antecedents and consequences of nonmedia information sources usage. It is suggested to investigate how these customized sources are associated with other variables, such as type of tourists, services performance, and sources' credibility. Finally, we encourage an

\footnotetext{
${ }^{3}$ We acknowledge an anonymous reviewer for this insight.
} 
application of the conceptual model to other services and other regions across the globe.

\section{CONCLUSIONS AND RESEARCH IMPLICATIONS}

The results also show that non-media information sources usage on tourist trip planning influences expectations fulfillment. The use of non-media information sources also has a direct impact on the future use of media information sources for future tourist trip planning, as well as an indirect impact through expectations fulfillment.

In the tourist's travel planning phase, consumers actively search for information from many sources, namely institutional and commercial brochures, travel agents and the internet. The use of these information sources is expected to have an impact on expectations fulfillment. Tourists who have more information, would be in a better position to create more realistic expectations about tourist destinations related to two specific aspects: region characteristics (inhabitants' friendliness, city/regional beauty and dinning quality) and (monuments, local attractions and events). We found that the main determinant of expectations fulfillment of regional characteristics is the use of travel agents, followed in relative importance by a negative impact of commercial brochures and positively by the internet.

We also found that expectations fulfillment of local infrastructures and entertainment structures are influenced in the first place by travel agents, institutional brochures and lastly, the internet.

Finally, we concluded that the determinant of future use of media sources is expectations fulfillment of local infrastructures and entertainment 
structures, followed by previous use of institutional brochures and past use of the internet.

The results showed that institutional brochures influence only expectations fulfillment related to local infrastructures and entertainment. There was no support to establish a relationship between the use of institutional brochures and regional characteristics expectations fulfillment. This partial result is probably due to the fact that these types of brochures usually have information about local tourist structures, more than regional characteristics.

Commercial brochures surprisingly showed only a significant and negative relationship with expectation fulfillment regarding characteristics of the region. A possible explanation is that these brochures show partial information about places. Commercial brochures are created by tourist firms and organizations that depict a more colorful image of their structures. When tourists arrive to destinations they can be faced with other realities.

Regarding travel agents and the internet, the results showed that they have a positive impact on destination expectations fulfillment. Travel agents, as suggested in other investigations (Murray 1991; Mitra, Reiss and Capella 1999), are a credible and reliable personal information source. The internet, as a complete and powerful information source, allows consumers to collect more and varied information about destinations.

Regarding the influence of expectations fulfillment in the future use of media sources in future trip planning, the results showed a partial relationship. We did not discover a significant relationship between regional characteristics expectations fulfillment and future use of media information sources. This result 
could be linked to the fact that tourists consider that media cannot give sufficient information about these factors because of their type and format of messages. However, local infrastructures expectations fulfillment has a positive impact on future use of media sources, perhaps because this kind of information is frequent in media that is more appealing, especially television.

As far as the relationship between use of non-media information sources in trip planning and future use of media sources in trip planning is concerned, the results were surprising. The use of institutional brochures has a positive impact on future use of media information sources, perhaps because they are more appealing. The relationship between commercial brochures use and future use of media information sources was not proved, perhaps because those types of information sources are similar, substituting one for the other. The results did not prove the negative relationship between travel agents use and media information sources in the future. But surprisingly, internet usage has a positive influence on media information sources on future trip planning. This could be due to the fact that the internet gives information similar to that of the media, so this information source enhances the use of media. 


\section{References}

Ader, J., LaFleur, R., \& Falcone, M. (2000). Internet Research [online] http:// www.bearstearns.com.

Ahmed, Z. U. (1996). The need for the identification of the constituents of a destination's tourist image: A promotion segmentation perspective. Services Marketing Quarterly, 14, 37-60.

Anderson, E.W, \& Salisbury, L.C. (2003). The formation of market-level expectations and its covariates. Journal of Consumer Research, 30, 115-124.

Bagozzi, R. P.(1981). Causal Models in Marketing. New York: John Wiley.

Baloglu, S., \& Brinberg, D. (1997). Affective images of tourism destinations. Journal of Travel Research, 35, 11-15.

Beatty, S.E., \& Smith, S.M. (1987). External search effort: An investigation across several product categories. Journal of Consumer Research, 14, 83-95.

Beldona, S. (2005). Cohort Analysis of online travel information search behaviour: 1995-2000. Journal of Travel Research, 44, 135-142.

Bettman, J.R., \& Park, C.W. (1980). Effects of prior knowledge and experience and phase of the choice processes: A protocol analysis. Journal of Consumer Research, 7, 234-48.

Bieger, T., Laesser, C., \& Gallen, S. (2000). Segmenting travel situations on the basis of motivation and information-collection by the traveller. Revue de Tourisme, 2, 54-64.

Bloch, M. (1996). Letter to travel agents, http://haas.berkley.edu/-citm.

Brucks, M. (1985) The effects of product class knowledge on information search behaviour. Journal of Consumer Research, 12, 1-16.

Buhalis, D. (1998). Strategic use of information technologies in the tourism industry. Tourism Management, 9, 409-421.

Connell, J., \& Reynolds, P. (1999). The implications of technological developments on tourist information centres. Tourism Management, 20, 501-509.

Connolly, D.J., \& Olsen, M.D. (2001). An environmental assessment of how technology is reshaping the hospitality industry. Tourism and Hospitality Research, 3, 73-93.

Cronbach, L. J. (1951). Coefficient alpha and the internal structure of tests. Psychometrika, 16, 297-334

Dodd, T.H., Pinkleton, B.E., \& Gustafson, A.W. (1996). External information sources of product enthusiasts: Differences between variety seekers, variety neutrals, and variety avoiders. Psychology and Marketing, 13, 291-304.

Dorsch, M.J., Grove, S.J., \& Darde, W.R. (2000). Consumer intentions to use a service category. The Journal of Services Marketing, 14, 92-108.

Echtner, C. M., \& Ritchie, J.R.B. (1991). The meaning and measurement of destination image. Journal of Tourism Studies, 2, 2-12.

Engel , J.F., Blackwell, R.D., \& Miniard, P.W. (1993). Consumer Behavior. Hillsdale, Illinois: The Dryden Press.

Filiatrault, O., \& Ritchie, J.R.B. (1980). Joint purchasing decisions: A comparison of influence structure in family and couple decision making units. Journal of Consumer Research, 7, 131-140.

Fodness, D., \& Murray, B. (1999). A model of tourist information search behaviour. Journal of Travel Research, 37, 220- 230.

Fornell, C., \& Larcker, D. (1981). Evaluating structural equation models with unobservable variables and measurement error. Journal of Marketing Research, 18, 39-50.

Gartner, W. C. (1989). Tourism image: Attribute measurement of state tourism products using muldimensional scaling techniques. Journal of Travel Research, 28, 16-20.

Ghose, S, \& Dou, W. (1998). Interactive functions and their impacts on the appeal of internet presence sites. Journal of Advertising Research, 4, 47-68.

Gitelson, R.J., \& Crompton, J.L. (1983). The planning horizons and sources of information used by pleasure vacationers. Journal of Travel Research, 21, 2-7.

Gunn, C. A. (1972). Vacationscape: Designing tourist regions. Austin: University of Texas, Bureau of Business Research.

Hodgson, P. (1993). Tour operator brochure design research revisited. Journal of Travel Research, 32, 50-51.

Hoffman, D.L., \& Novak, T.P. (1996). Marketing in hypermedia computer-mediated environments: Conceptual foundations. Journal of Marketing, 60, 50-68. 
Hugstad, P., Taylor, J.W., \& Bruce, G.D. (1987). The effects of social class and perceived risk on consumer information search. Journal of Services Marketing, 1, 47-52.

Jenkins, R.L. (1978). Family vacation decision-making. Journal of Travel Research, 16, 2-7.

Jöreskog K. G., \& Sörbom, D. (1993). LISREL 8: Structural Equation Modelling with the SIMPLIS Command Language. Hillsdale NJ: Lawrence Erlbaum Associates.

Kaid, L.L. (2002) Political advertising and information seeking: Comparing exposure via traditional and internet channels. Journal of Advertising, 31, 27-35.

Kempf, D.S., \& Smith, R.E. (1998) Consumer processing of product trial and the influence of prior advertising: A structural modelling approach. Journal of Marketing Research, 35, 325338.

Lages, L.F., \& Lages, C.R. (2004). The STEP scale: A measure of short-term export performance improvement. Journal of International Marketing, 12, 36-56.

Lages, L.F., \& Montgomery, D.B. (2004) Export performance as an antecedent of export commitment and marketing strategy adaptation: Evidence from small and medium sized exporters. European Journal of Marketing, 38, 1186-1214.

Lages, L.F., \& Montgomery, D.B. (2005). The relationship between export assistance and performance improvement in Portuguese export ventures: An empirical testing of the mediating role of pricing strategy adaptation. European Journal of Marketing, 39, 755-784.

Leong, E.K.F., Huang, X, \& Stanners, P.J. (1998). Comparing the effectiveness of the web site with traditional media. Journal of Advertising Research, 38(5), 44-51.

Lovelock, C., Vandermerwe S., \& Lewis, B. (1999). Services marketing: A European perspective. USA: Prentice-Hall.

Manfredo, M.J. (1989). An investigation of the basis for external information search in recreation and tourism. Leisure Sciences, 11, 29-45.

McColl-Kennedy, J.R., \& Fetter Jr, R.E. (1999). Dimensions of consumer search behaviour in services. The Journal of Services Marketing, 13, 242-156.

Menon, S., \& Soman, D. (2002). Managing the power of curiosity for effective web advertising strategies. Journal of Advertising, 31, 1-13.

Miles, P. (1995). Portugal: Tourism goes upscale. Europe, April, 31-32.

Mitra, K., Reiss, M.C., \& Capella, L.M. (1999). An examination of perceived risk, information search and behavioral intentions in search, experience and credence services. The Journal of Services Marketing, 13, 208-222.

Moore, E.S., Lutz, J.R. (2000). Children, advertising, and product experiences: a multimethod inquiry. Journal of Consumer Research, 27, 31-48.

Morrison, A.J., \& King, B.E.M. (2002). Small tourism businesses and e-commerce: Victorian tourism online. Tourism and Hospitality Research, 4, 104-115.

Moutinho, L. (1987). Consumer behaviour in tourism. European Journal of Marketing, 21, 5-44.

Moutinho, L. (2000). Consumer behaviour. In L.Moutinho (ed.) Strategic Management in Tourism (pp. 41-79). New York: CABI Publishing.

Moutinho, L., \& Goode, M. (1995). Gender effects to the formation of overall product satisfaction: A multivariate approach. Journal of International Consumer Marketing, 8, 7191.

Murphy, M., Murphy, L. (2002) 'See you in three months' An extended stay is one of the best ways to visit Europe; Here's how to start. Wall Street Journal, June, p.R.6.

Murray, K. B. (1991). A test of services marketing theory: Consumer information acquisition activities. Journal of Marketing, 55, 10-25.

Neelamegham, R., \& Jain, D. (1999). Consumer choice process for experience goods: An econometric model and analysis. Journal of Marketing Research, 36, 373-386.

Nolan, D. (1976). Tourist's use and evaluation of travel information. Journal of Travel Research, 14, 6-8.

Parasuraman, A., Zeithaml, V.S., \& Berry, L.L. (1988). SERVQUAL: A multiple-item scale for measuring consumer perceptions of service quality. Journal of Retailing, 64, 12-40.

Parasuraman, A., Zinkhan, G.M. (2002). Marketing to and serving customers through the internet: An overview and research agenda. Journal of the Academy of Marketing Science, 30, 286-295.

Perdue, R.R. (1985). Segmenting state travel information inquirers by timing of the destination decision and previous experience. Journal of Travel Research, 23, 6-11. 
Peterson, R.A., Balasubramanian, S., \& Bronnenberg, B.J. (1997). Exploring the implications of the internet for consumer marketing. Academy of Marketing Science Journal, 3, 114-143.

Raitz, K., \& Dakhil, M. (1989). A note about information sources for preferred recreational environments. Journal of Travel Research, 27, 45-50.

Reardon, K.K., \& Rogers, E.M. (1988). Interpersonl versus mass communication: a false dichotomy. Human Communication Research, 12, 284-303.

Shoemaker, S. (1984). Marketing to older travellers. The Cornell Quarterly, 25, 84-91.

Siegel, W., \& Ziff-Levine, W. (1990). Evaluating tourism advertising campaigns: Conversion versus advertising tracking studies. Journal of Travel Research, 28, 51-55.

Smith, R.E. (1993). Integrating information from advertising and trial: Processes and effects on consumer response to product information. Journal of Marketing Research, 30, 204-219.

Snepenger, D., Meged, K., Snelling, L., \& Worral, K. (1990). Information search strategies by destination-naïve tourists. Journal of Travel Research, 29, 13-16.

Snepenger, D.J. (1987). Segmenting the vacation market by novelty-seeking role. Journal of Travel Research, 26, 8-14.

Spreng, R.A., \& Page Jr., T.J. (2001). The impact of confidence in expectations on consumer satisfaction. Psychology and Marketing, 18, 1187-1197.

Srinivasan, N., \& Ratchford, B.T. (1991). An empirical test of a model of external search for automobiles. Journal of Consumer Research, 18, 233-242.

Stabler, M.J. (1988). The image of destination regions: Theoretical and empirical aspects. In Goodall, B., \& Ashworth, G. (eds.), Marketing in tourism industry - The promotion of destination regions (pp. 133-159). London: Routledge.

Wise, P. (2005). Tourism: Subtlety aims to replace faded charms of the Algarve. In www.financialtimes.com.

Wyner, G. (2000). Learn and earn through testing on the internet. Marketing Research, 12, 3738.

Wynne, C., Berthon, P. P., Pitt, L., Ewing, M., \& Napoli, J. (2001). The impact of the Internet on the distribution value chain: The case of the South African tourism industry. International Marketing Review, 18, 420-431.

Zeithaml, V. A. (1981). How consumer evaluation processes differ between goods and services. In J. H. Donnelly and W. R. George (eds.) Marketing of Services (pp. 186-90). Chicago: American Marketing Association.

Zeithaml, V.A., Parasuraman, A., \& Berry, L.L. (1985). Problems and strategies in services marketing. Journal of Marketing, 49, 33-46. 


\section{TABLE 1: EFFECTS OF EXOGENOUS AND PRIOR}

\section{ENDOGENOUS CONSTRUCTS}

(Maximum likelihood estimation, $\mathrm{N}=350$ )

\begin{tabular}{|c|c|c|c|c|c|c|c|c|c|}
\hline \multirow[t]{2}{*}{$\begin{array}{l}\text { EFFECT OF / } \\
\text { ON }\end{array}$} & \multicolumn{3}{|c|}{$\begin{array}{l}\eta_{1} \\
\text { Expectations } \\
\text { fulfillment regarding } \\
\text { characteristics of the } \\
\text { Region }\end{array}$} & \multicolumn{3}{|c|}{$\begin{array}{l}\mathrm{\eta}_{2} \\
\text { Expectations } \\
\text { fulfillment regarding } \\
\text { local infrastructures } \\
\text { and entertainment } \\
\text { structures }\end{array}$} & \multicolumn{3}{|c|}{$\begin{array}{l}\eta_{3} \\
\text { Future use of media } \\
\text { sources }\end{array}$} \\
\hline & Direct & Indirect & Total & Direct & Indirect & Total & Direct & Indirect & Total \\
\hline $\begin{array}{c}\xi 1 \\
\begin{array}{c}\text { Institutional } \\
\text { brochure }\end{array}\end{array}$ & $\begin{array}{l}0.01 \\
(0.08) \\
\text { H1a } \\
\end{array}$ & & $\begin{array}{l}0.01 \\
(0.08)\end{array}$ & $\begin{array}{r}0.21 * * \\
(2.61) \\
\text { H2a } \\
\end{array}$ & & $\begin{array}{c}0.21 * * \\
(2.61)\end{array}$ & $\begin{array}{c}0.42 * * \\
(5.82) \\
\\
\text { H4 } \\
\end{array}$ & $\begin{array}{c}0.09 * \\
(2.55)\end{array}$ & $\begin{array}{r}\mathbf{0 . 5 1} * * \\
(6.42)\end{array}$ \\
\hline $\begin{array}{c}\xi 2 \\
\text { Commercial } \\
\text { brochures }\end{array}$ & $\begin{array}{r}-\mathbf{0 . 5 5 * *} \\
(-3.13) \\
\text { H1b }\end{array}$ & & $\begin{array}{r}-0.55 * * \\
(-3.13)\end{array}$ & $\begin{array}{l}-0.28 \\
(-1.66) \\
\mathrm{H} 2 \mathrm{~b}\end{array}$ & & $\begin{array}{l}-0.28 \\
(-1.66)\end{array}$ & $\begin{array}{l}-0.18 \\
(-1.24) \\
\text { H5 }\end{array}$ & $\begin{array}{l}-0.12 \\
(-1.50)\end{array}$ & $\begin{array}{l}-0.30 \\
(-1.91)\end{array}$ \\
\hline $\begin{array}{c}\xi 3 \\
\text { Travel agents }\end{array}$ & $\begin{array}{r}0.70 * * \\
(4.20) \\
\text { H1c }\end{array}$ & & $\begin{array}{r}\mathbf{0 . 7 0} * * \\
(4.20)\end{array}$ & $\begin{array}{c}0.37 * \\
(2.36) \\
\text { H2c }\end{array}$ & & $\begin{array}{c}\mathbf{0 . 3 7} * \\
(\mathbf{2 . 3 6})\end{array}$ & $\begin{array}{l}-0.01 \\
(-0.09) \\
\text { H6 }\end{array}$ & $\begin{array}{l}0.15 \\
(2.00)\end{array}$ & $\begin{array}{l}0.14 \\
(0.98)\end{array}$ \\
\hline $\begin{array}{c}\xi 4 \\
\text { Internet }\end{array}$ & $\begin{array}{r}\text { 0.18** } \\
(2.62) \\
\text { H1d }\end{array}$ & & $\begin{array}{r}0.18 * * \\
(2.62)\end{array}$ & $\begin{array}{r}\mathbf{0 . 2 0} * * \\
(3.04) \\
\text { H2d }\end{array}$ & & $\begin{array}{r}0.20 * * \\
(3.04)\end{array}$ & $\begin{array}{c}\mathbf{0 . 1 5 ^ { * * }} \\
(2.69) \\
\text { H7 }\end{array}$ & $\begin{array}{r}\mathbf{0 . 0 8} * * \\
(2.77)\end{array}$ & $\begin{array}{r}\mathbf{0 . 2 4} * * \\
(3.83)\end{array}$ \\
\hline $\begin{array}{l}\eta_{1} \\
\text { Characteristics } \\
\text { of the region }\end{array}$ & & & & & & & $\begin{array}{r}-0.01 \\
(-0.09) \\
\\
\text { H3a } \\
\end{array}$ & & $\begin{array}{c}-0.01 \\
(-0.09)\end{array}$ \\
\hline $\begin{array}{c}\eta_{2} \\
\text { Local } \\
\text { infrastructures } \\
\text { and } \\
\text { entertainment } \\
\text { structures }\end{array}$ & & & & & & & $\begin{array}{r}0.43 * * \\
(6.55) \\
\text { H3b }\end{array}$ & & $\begin{array}{r}0.43 * * \\
(6.55)\end{array}$ \\
\hline
\end{tabular}

Notes: Values in upper rows are completely standardized estimates. Values in lower rows are tvalues.

$$
* \mathrm{p}<0.05, * * \mathrm{p}<0.01 \text { (two-tailed test) }
$$

Because of rounding, sometimes the "total effect" is not the same as "the direct effect plus the indirect effect".

The signs for the expected indirect and total effects were established by implication. We assume that if all the direct relationships involved in an indirect relationship are positive, the final indirect relationship is also expected to be positive. The same principle applies to the total effects. If both direct and indirect effects are expected to be positive, then the sign for the total effect is also expected to be positive (Lages and Montgomery 2004, 2005). 
(Scale $1=$ Not important $/ 7$ = Extremely important)

Importance of information from institutional brochures ${ }^{1}(\alpha=.79)$

$\begin{array}{lll}\text { V1 Importance of institutional brochures to route selection. } & 0.87\end{array}$

V2 Importance of institutional brochures to accommodation selection.

${ }^{1}$ Adapted from: Nolan 1976; Snepenger 1987; Snepenger et al. 1990; Raitz and Dakhil 1989; Fodness and Murray 1999.

Importance of information from commercial brochures ${ }^{2}(\alpha=.91)$

V4 Importance of commercial brochures to route selection.

V5 Importance of commercial brochures to accommodation selection.

V6 Importance of commercial brochures to activities selection.

Adapted from: Bieger et al. 2000; Hodgson 1993.

Importance of information from travel agents ${ }^{3} \quad(\alpha=.95)$

V7 Importance of travel agents to route selection.

V8 Importance of travel agents to accommodation selection.

V9 Importance of travel agents to activities selection.

${ }^{3}$ Adapted from: Ader, LaFleur and Falcone 2000; Connolly and Olsen 2001; Gitelson and Crompton 1983; Morrison and King 2002; Murray 1991; Nolan 1976; Shoemaker 1984; Snepenger 1987; Wynne et al. 2001.

Importance of information from internet ${ }^{4}(\alpha=.93)$

V10 Importance of internet to route selection.

V11 Importance of internet to accommodation selection.

V12 Importance of internet to activities selection.

${ }^{4}$ Adapted from: Bieger et al. 2000; Bloch 1996; Buhalis 1998, Connel and Reynolds 1999; Lovelock et al. 1999; Parasuraman and Zinkhan 2002; Wynne et al. 2001; Wyner 2000.

\section{EXPECTATIONS FULFILLMENT}

(Scale 1 = It didn't come up to any of your expectations / 7 = It was really beyond your expectations)

Tourist Destination Region Characteristics ${ }^{5}(\alpha=.80)$

V13 Inhabitants' friendliness

V14 City/Region Beauty

${ }^{5}$ Adapted from: Ahmed 1996; Bieger et al. 2000; Echtner and Ritchie 1991, 1993; Engel et al. 1993; Spreng and Page 2001.

Local infrastructures and entertainment ${ }^{6}(\alpha=.88)$

V16 Local infrastructures

${ }^{6}$ Adapted from: Ahmed 1996; Bieger et al. 2000; Echtner and Ritchie 1991, 1993; Engel et al. 1993; Spreng and Page 2001.

\section{FUTURE USE OF MEDIA SOURCES}

(Scale $1=$ Not important $/ 7$ = Extremely important)

Future use of media sources ${ }^{7}(\alpha=.87)$

V20 Advertising on media

V21 Media information

7 Adapted from: Beatty and Smith 1987; Dodd et al. 1996; Dorsch et al. 2000; Gartner 1989; Manfredo, et al. 1992; Mitra et al. 1999; Moore and Lutz 2000; Moutinho and Goode 1995; Raitz and Dakhil 1989; Siegel and ZiffLevine 1990; Smith 1993; Zeithmal et al. 1985.

Notes: $\alpha=$ Internal reliability (Cronbach 1951) 
FIGURE 1

CONCEPTUAL FRAMEWORK

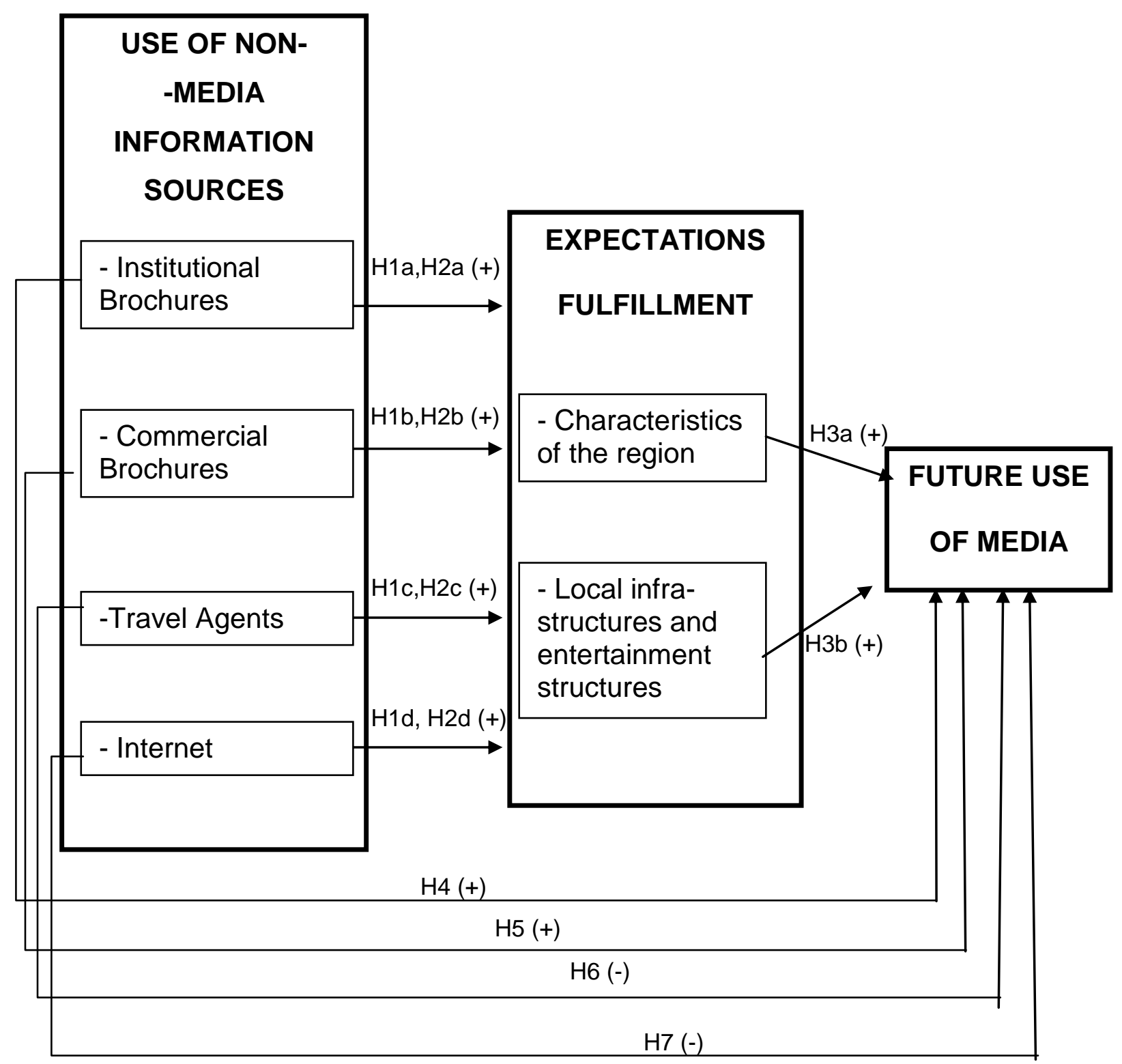


FIGURE 2

\section{SUMMARY OF SIGNIFICANT RELATIONSHIPS ${ }^{a}$}

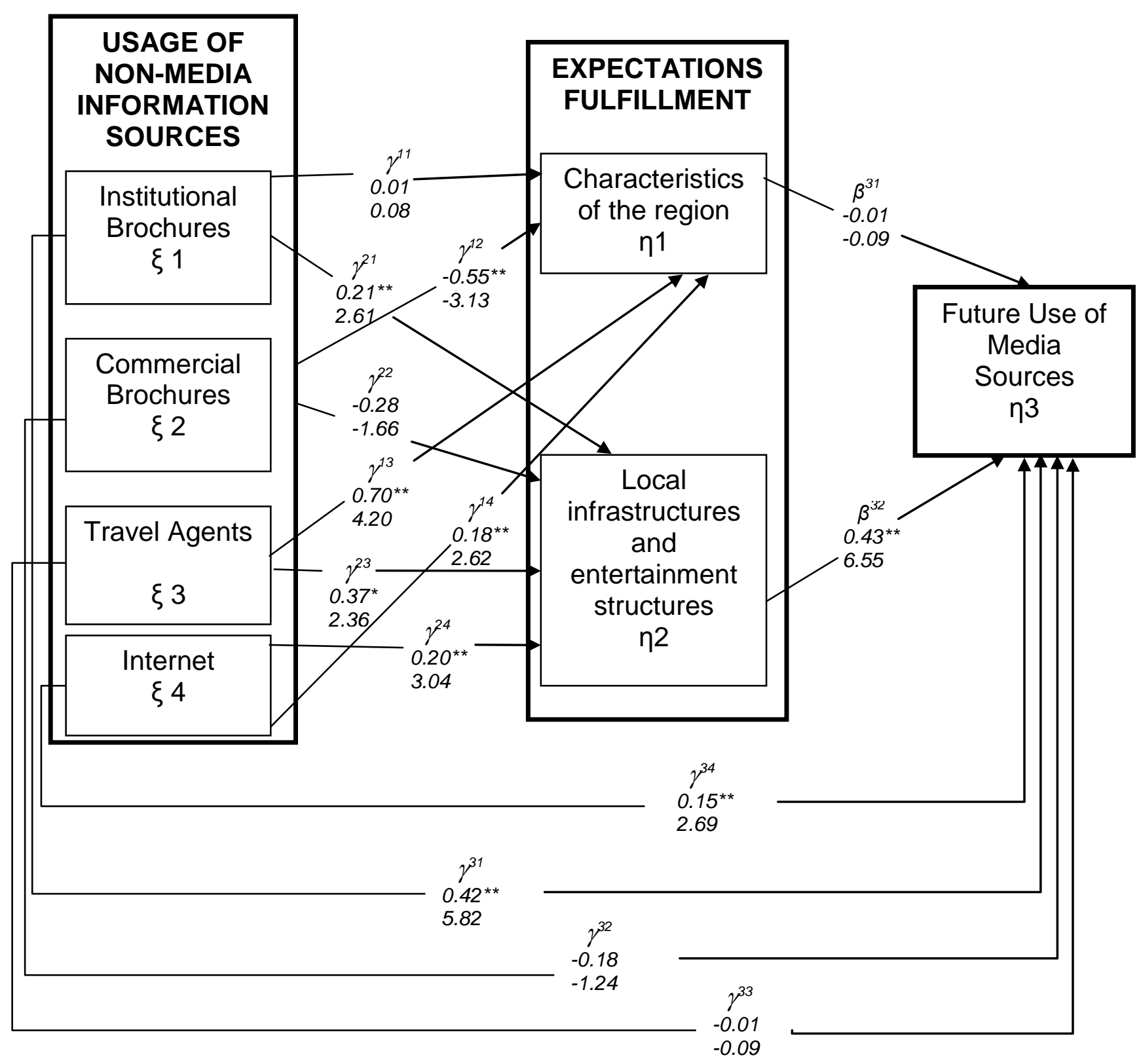

${ }^{a}$ Values in upper rows are completely standardized estimates. Values in lower rows are t-values. ${ }^{*} p<0.05,{ }^{* *} p<0.01$ (two-tailed test). The standardized coefficients indicate how a typical variation in the independent variable leads to, or is associated with, a typical change or variation in the dependent variable (Goldberger 1964). They give an indication of relative importance to the dependent variable. 